\title{
An Evaluation of Bioenergy Industry Sustainability Impacts on Forest Degradation in The EU 28 Region
}

Mohd Alsaleh ( $\square$ moe_saleh222@hotmail.com )

Shanghai University

\section{A.S. Abdul-Rahim}

Universiti Putra Malaysia

\section{Research}

Keywords: Bioenergy use, institutional quality, forest degradation, sustainability

Posted Date: July 17 th, 2020

DOI: https://doi.org/10.21203/rs.3.rs-41186/v2

License: (c) (1) This work is licensed under a Creative Commons Attribution 4.0 International License. Read Full License 
The authors have withdrawn this preprint from Research Square 